\title{
Financing the Counteraction of Natural Disasters' Effects in Lower Silesian Voivodeship
}

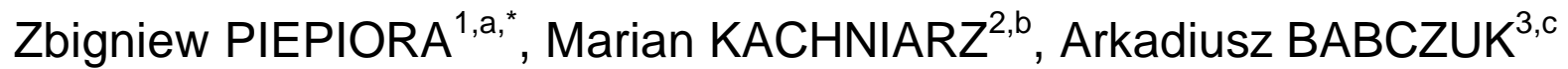 \\ ${ }^{1}$ Wrocław University of Environmental and Life Sciences The Faculty of Environmental Engineering \\ and Geodesy Department of Land Management ul. Grunwaldzka 53, 50-357 Wrocław, Poland \\ ${ }^{2}$ Wrocław University of Economics The Faculty of Economics, Management and Tourism \\ Department of Land Management, ul. Nowowiejska 3, 58-500 Jelenia Góra, Poland \\ ${ }^{3}$ Wrocław University of Economics The Faculty of Economics, Management and Tourism \\ Department of Finances and Accounting ul. Nowowiejska 3, 58-500 Jelenia Góra, Poland \\ azbigniew.piepiora@up.wroc.pl, ’’marian.kachniarz@ue.wroc.pl, arkadiusz.babczuk@ue.wroc.pl \\ ${ }^{*}$ Corresponding author
}

Keywords: Natural disaster, Counteraction, Effects, Lower silesian voivodeship, Region.

\begin{abstract}
Authors present the financial aspects of the counteraction of the natural disasters' effects. On the background of the conducted analysis in of Lower Silesian voivodeship (NUTS 2) in Poland, following conclusions can be drawn. Expenses for counteracting the natural disasters' effects were co-financed from the ecological funds. One of them is the Fund for Environmental Protection and Water Management. Expenses for the permanent assets serving the water management in Lower Silesian voivodeship in the years 1998-2013 amounted approx. 1.5 billon US dollars indexed to the year 2013. Investing expenses for the low water retention in the area of the examined region in the years 2003-2013 exceeded 19 million US dollars. The range of objects in Lower Silesian voivodeship in the years 2003-2013 amounted 525. Total increasing capacity in the examined period exceeded 5.5 million $\mathrm{m}^{3}$. The share of expenses for removing effects of the natural disasters in the expenditures for public safety, fire and health protection is minimal.
\end{abstract}

\section{Introduction}

In the years 1997 and 2010, Lower Silesian voivodeship in Poland was affected by two great floods. Destructive hurricanes occurred in the examined area in 2005 and 2007 (orcan Kyrill). Between these years, Lower Silesian voivodeship was affected by drought $[7,8,14]$.

Floods, hurricanes and droughts are natural disasters. The natural disaster is an unforeseen and often sudden event that causes great damage, destruction and human suffering. It can be defined as the situation or the event, which overwhelms local capacity, necessitating a request to national or international level for external assistance [4]. The natural disasters are started by the natural hazards - the probability of occurrence of a dangerous event [1]. There are biological, geological and hydrometeorogical factors of these events [15]. The natural catastrophes have large impact on very poor and very rich societies. The former present the highest casualty totals and the latter the highest property damages [2].

In relation to the negative consequences caused by the natural disasters, the crucial significance for the economy of the each region has preventing the effects of these kinds of events. The aim of this article is to present counteracting the natural disasters' effects in Lower Silesian voivodeship in Poland. Authors used the methodology of Zbigniew Piepiora[9] and extended his research from floods[10] to all types of natural disasters and the examined period from 1998-2011 to 1998-2013[11, 12] concerning on the financial issues[5].

\section{Counteracting the natural disasters' effects in the examined area}

Lower Silesian voivodeship (also called 'province') is located in the south-west part of Poland which is the member of the European Union. It borders with the provinces; Lubusz, Geater Poland, Opole. Moreover, it borders with Germany $(70 \mathrm{~km})$ and Czech Republic (the length $340 \mathrm{~km}) .60 \%$ of Lower Silesian voivodeship is situated in the area near the border. The present border of Lower Silesian and 
Greater Poland provinces is a historic border between the Silesia and Greater Poland, created in the Middle Ages. From the year 1939 it was also the border between Germany and Poland. The south border in the Sudety Mountains (Sudetes) was formed finally in the 19th century. The actual shape of the province reminds the Wrocław Province before year 1975 with the lined Głogow and the environs [8, 11, 13].

The examined province occupies $19948 \mathrm{~km}^{2}$ of area and it has the seventh position in Poland (which is $6,4 \%$ of Poland's territory), the number of inhabitants is approx. 2.9 million (which is approx. $7 \%$ of Poland's population). The area is characterized by the high level of population density, approx. 145 people per $1 \mathrm{~km}^{2}$ but the population density differs in different parts of the examined region [12].

The biggest city of the province is Wrocław with approx. 640 thousand inhabitants. Other big cities are: Wałbrzych (approx. 120 thousand), Legnica (approx. 102 thousand), Jelenia Góra (83 thousand inhabitants). The cities with over 60 thousand inhabitants are: Lubin, Głogów and Świdnica[16].

Expenses for the permanent assets serving the water management in Lower Silesian voivodeship in the years 1998-2013 amounted approx. 1.5 billon US dollars indexed to the year 2013. Expenditures for levees in the years after the floods in 1997 (expenses in the years 1998 and 1999) and 2010 (expenses in the years 2011-2013) were significant higher and amounted approx. average 20 million US dollars every year. Expenses in the years 2000-2010 leveled down and amounted approx. average 5 million US dollars every year[3, 6].

The main source of the expenditures for permanent assets serving the water management in the examined area in the years 2002-2013 which totally exceeded 1 billion US dollars were own measures. From these sources, there were financed approx. 34\% of total expenditures in the examined period [3, 6].

The effects of investing in the water management in the years 2003-2013 in Lower Silesian voivodeship are corresponding with the expenditures. In the years 2001-2010, the number of kilometers of levees which were built amounted approx. $6 \mathrm{~km}$ every year. In the period 2011-2013 there were built approx. $8 \mathrm{~km}$ levees every year [3].

The expenses for counteracting the natural disasters' effects were co-financed from ecological funds. One of these funds is the Fund for Environmental Protection and Water Management. The charges and incomes to this fund in Lower Silesian voivodeship in the years 2002-2013 amounted approx. 611 million US dollars. The incomes from charges for the waste management were the main part of total incomes and exceeded 255 million US dollars [3, 6].

Table 1 The investing expenses for the low water retention in Lower Silesian voivodeship - the investing directions in the years 2002-2013 [in '000 US dollars indexed to the year 2013]

\begin{tabular}{|c|c|c|c|c|c|c|c|}
\hline Years & Total & $\begin{array}{c}\text { Man-made } \\
\text { water reservoirs }\end{array}$ & $\begin{array}{c}\text { Independent } \\
\text { staging } \\
\text { structures and } \\
\text { water intakes on } \\
\text { primary } \\
\text { water-races }\end{array}$ & $\begin{array}{l}\text { Independent } \\
\quad \text { staging } \\
\text { structures and } \\
\text { water intakes } \\
\text { on secondary } \\
\text { water-races }\end{array}$ & $\begin{array}{l}\text { Staging } \\
\text { lakes }\end{array}$ & $\begin{array}{l}\text { Fish } \\
\text { ponds }\end{array}$ & Other \\
\hline 2003 & 4609 & 2365 & 6 & 19 & 0 & 2204 & 15 \\
\hline 2004 & 3524 & 3168 & 0 & 3 & 0 & 352 & 1 \\
\hline 2005 & 2806 & 2156 & 0 & 4 & 0 & 645 & 1 \\
\hline 2006 & 2635 & 1228 & 10 & 9 & 0 & 1372 & 16 \\
\hline 2007 & 1216 & 559 & 26 & 23 & 0 & 595 & 13 \\
\hline 2008 & 1538 & 304 & 18 & 6 & 0 & 1183 & 27 \\
\hline 2009 & 1047 & 206 & 0 & 0 & 0 & 842 & 0 \\
\hline 2010 & 1053 & 66 & 0 & 3 & 0 & 975 & 0 \\
\hline 2011 & 438 & 150 & 11 & 0 & 0 & 276 & 1 \\
\hline 2012 & 138 & 32 & 0 & 0 & 0 & 107 & 0 \\
\hline 2013 & 60 & 13 & 0 & 0 & 0 & 47 & 0 \\
\hline Total-all years & 19064 & 10247 & 71 & 67 & 0 & 8597 & 74 \\
\hline
\end{tabular}

Source: Own study on the basis of: $[3,6]$.

The investing expenses for the low water retention in the area of the examined region in the years 2003-2013 according to the investing directions are presented in the table 1. As we can see, the investing 
expenditures for man-made water reservoirs exceeded over 10 million US dollars. The total investing expenses for the low water retention exceeded 19 million US dollars [3, 6].

The investing expenses for the low water retention in Lower Silesian voivodeship in the years 2003-2013 according to the financing sources are presented in the table 2. As we can see, the expenses were financed mainly from the Fund for Environmental Protection and Water Management (approximately 22\%).

Table 2 The investing expenses for the low water retention in Lower Silesian voivodeship in the years 2003-2013 - the financing sources [in '000 US dollars indexed to the year 2013]

\begin{tabular}{|c|c|c|c|c|c|c|c|}
\hline & Total & $\begin{array}{c}\text { From } \\
\text { budget } \\
\text { of } \\
\text { voivod }\end{array}$ & $\begin{array}{c}\text { From fund for } \\
\text { environmental } \\
\text { protection and } \\
\text { water management }\end{array}$ & $\begin{array}{c}\text { From fund } \\
\text { for protection } \\
\text { rural areas }\end{array}$ & $\begin{array}{c}\text { From eu's } \\
\text { structural } \\
\text { funds }\end{array}$ & $\begin{array}{c}\text { From } \\
\text { budgets of } \\
\text { self-govern } \\
\text { ments }\end{array}$ & Other \\
\hline 2003 & 4609 & 1074 & 305 & 398 & 0 & 359 & 2473 \\
\hline 2004 & 3524 & 1604 & 1495 & 102 & 0 & 46 & 277 \\
\hline 2005 & 2806 & 751 & 1384 & 118 & 0 & 16 & 537 \\
\hline 2006 & 2635 & 282 & 660 & 238 & 0 & 224 & 1232 \\
\hline 2007 & 1216 & 98 & 163 & 165 & 0 & 235 & 554 \\
\hline 2008 & 1538 & 34 & 0 & 248 & 0 & 175 & 1082 \\
\hline 2009 & 1047 & 0 & 0 & 142 & 0 & 47 & 68 \\
\hline 2010 & 1053 & 0 & 0 & 165 & 0 & 38 & 849 \\
\hline 2011 & 438 & 0 & 107 & 48 & 0 & 163 & 168 \\
\hline 2012 & 138 & 0 & 27 & 84 & 5 & 0 & 27 \\
\hline 2013 & 60 & 0 & 0 & 11 & 0 & 0 & 49 \\
\hline Total-all years & 19064 & 3841 & 4141 & 1721 & 5 & 1304 & 7315 \\
\hline
\end{tabular}

Source: Own study on the basis of: $[3,6]$.

The effects of investing in the low water retention are presented in the table 3 . The range of objects in Lower Silesian voivodeship in the years 2003-2013 amounted 525. The total increasing capacity in the examined period exceeded 5.5 million $\mathrm{m}^{3}$.

Table 3 The effects of investing in the low water retention - the range of objects in Lower Silesian voivodeship in the years 2003-2013

\begin{tabular}{|c|c|c|c|c|c|c|c|c|}
\hline Years & Objects & $\begin{array}{c}\text { Invreasing } \\
\text { capacity }\end{array}$ & $\begin{array}{c}\text { Staging } \\
\text { of lakes }\end{array}$ & $\begin{array}{c}\text { Artificial } \\
\text { water } \\
\text { reservoirs }\end{array}$ & & $\begin{array}{c}\text { Fish } \\
\text { ponds }\end{array}$ & \\
\hline Units of measure & 1. & 2. & 1. & 2. & 2. & $\mathrm{~km}$ & unit & $\mathrm{km}$ \\
\hline 2003 & 91 & 1212 & 0 & 0 & 3 & 316 & 76 & 896 \\
\hline 2004 & 22 & 303 & 0 & 0 & 1 & 133 & 19 & 170 \\
\hline 2005 & 58 & 337 & 0 & 0 & 1 & 3 & 40 & 334 \\
\hline 2006 & 55 & 1484 & 0 & 0 & 2 & 881 & 47 & 603 \\
\hline 2007 & 55 & 618 & 0 & 0 & 13 & 351 & 33 & 268 \\
\hline 2008 & 62 & 447 & 0 & 0 & 12 & 52 & 35 & 395 \\
\hline 2009 & 41 & 231 & 0 & 0 & 19 & 32 & 22 & 199 \\
\hline 2010 & 335 & 371 & 0 & 0 & 304 & 24 & 29 & 347 \\
\hline 2011 & 36 & 259 & 0 & 0 & 7 & 39 & 27 & 220 \\
\hline 2012 & 29 & 265 & 0 & 0 & 10 & 88 & 19 & 178 \\
\hline 2013 & 13 & 41 & 0 & 0 & 5 & 8 & 8 & 32 \\
\hline Total-all years & 525 & 5574 & 0 & 0 & 377 & 1927 & 355 & 3641 \\
\hline
\end{tabular}

1. Objects [units], 2. Capacity ['000 $\left.\mathrm{m}^{3}\right]$

Source: Own study on the basis of: [3].

The total expenses for removing the natural disasters' effects according to the budget classification in Lower Silesian voivodeship in the years 2008-2013 are amounted approx. 366 million US dollars. The largest share in the expenses for removing effects of these kind of phenomena had measures from the budgets of municipalities (55.9\%) and the smallest - from the budgets of counties $(21.5 \%)$. The largest 
part of measures from budgets of counties and municipalities were spent for the transport and communication - almost 200 million US dollars. From the budget of Lower Silesian voivodeship, there were mainly financed the expenses in agriculture and hunting (76.3 million US dollars) [3, 6].

Table 4 The expenditures for public safety, fire and health protection in Lower Silesian voivodeship according to the divisions of the budget classification in the years 2008-2013 [in '000 US dollars indexed to the year 2013]

\begin{tabular}{|c|c|c|c|c|}
\hline & $\begin{array}{l}\text { Public safety } \\
\text { (ps) and fire } \\
\text { protection (fp) }\end{array}$ & $\begin{array}{l}\text { Share of measures } \\
\text { of individual } \\
\text { budgets in total } \\
\text { expenditures for ps } \\
\text { and fp }\end{array}$ & $\begin{array}{c}\text { Health } \\
\text { protection (hp) }\end{array}$ & $\begin{array}{c}\text { Share of measures } \\
\text { of individual } \\
\text { budgets in total } \\
\text { expenditures for hp }\end{array}$ \\
\hline $\begin{array}{l}\text { Measures from budget of } \\
\text { Lower Silesian } \\
\text { voivodeship }\end{array}$ & 5715 & $1 \%$ & 254501 & $36 \%$ \\
\hline $\begin{array}{c}\text { Measures from budgets } \\
\text { of counties }\end{array}$ & 215940 & $39 \%$ & 251930 & $36 \%$ \\
\hline $\begin{array}{l}\text { Measures from budgets } \\
\text { of municipalities }\end{array}$ & 326077 & $60 \%$ & 199606 & $28 \%$ \\
\hline Total & 547731 & $100 \%$ & 706037 & $100 \%$ \\
\hline Total ps, fp and hp & \multicolumn{4}{|c|}{1253769} \\
\hline
\end{tabular}

Source: Own study on the basis of: [3, 6].

The expenditures for public safety, fire and health protection in Lower Silesian voivodeship according to the divisions of the Budget Classification in the years 2008-2013 are presented in the table 4. As we can see, the total expenses in the examined period amounted approx. 1.3 billion US \$. The largest share in the expenditures for the public safety and fire protection had the budgets of municipalities. The largest share in the expenses for the health protection had the budgets of counties and the budget of Lower Silesian voivodeship.

Table 5 The share of the expenses for removing effects of natural disasters in the expenditures for public safety, fire and health protection in Lower Silesian voivodeship according to the divisions of the budget classification in the years 2008-2013 [in '000 US dollars indexed to the year 2013]

\begin{tabular}{|c|c|c|c|c|c|c|}
\hline & $\begin{array}{l}\text { Expenses } \\
\text { for public } \\
\text { safety and } \\
\text { fire } \\
\text { protection }\end{array}$ & $\begin{array}{l}\text { Including: } \\
\text { removing } \\
\text { natural } \\
\text { disasters } \\
\text { effects }\end{array}$ & $\begin{array}{l}\text { Share of } \\
\text { measures for } \\
\text { removing } \\
\text { natural } \\
\text { disasters } \\
\text { effects in } \\
\text { expenditures } \\
\text { for public } \\
\text { safety and fire } \\
\text { protection }\end{array}$ & $\begin{array}{l}\text { Expenses } \\
\text { for health } \\
\text { protection }\end{array}$ & $\begin{array}{l}\text { Including: } \\
\text { natural } \\
\text { disasters } \\
\text { effects }\end{array}$ & $\begin{array}{c}\text { Share of } \\
\text { measures for } \\
\text { natural } \\
\text { disasters } \\
\text { effects in } \\
\text { expenditures } \\
\text { for health } \\
\text { protection }\end{array}$ \\
\hline $\begin{array}{l}\text { Measures from } \\
\text { budget of the } \\
\text { Lower Silesian } \\
\text { voivodeship }\end{array}$ & 5715 & 0 & $0,0 \%$ & 254501 & 0 & $0,0 \%$ \\
\hline $\begin{array}{l}\text { Measures from } \\
\text { budgets of } \\
\text { counties }\end{array}$ & 215940 & 3644 & $1,7 \%$ & 251930 & 0 & $0,0 \%$ \\
\hline $\begin{array}{l}\text { Measures from } \\
\text { budgets of } \\
\text { municipalities }\end{array}$ & 326077 & 8033 & $2,5 \%$ & 199606 & 426 & $0,2 \%$ \\
\hline Total & 547731 & 11676 & $2,1 \%$ & 706037 & 426 & $0,1 \%$ \\
\hline
\end{tabular}

Source: Own study on the basis of: $[3,6]$. 
Considering the data from tables 4 and 5, it is worth noting the minimal share of the expenses for removing the effects of natural disasters in the expenditures for the public safety, fire and health protection. As we can see, only 12 million US dollars expenses were spent for counteracting the negative consequences of natural disasters from 548 million US \$ expenditures for the public safe and fire protection. Only approx. 0.5 million US dollars expenses were spent for counteracting the negative consequences of this kind phenomena from 706 million US \$ expenditures for the health protection.

\section{Conclusion}

After conducted analysis in Lower Silesian voivodeship in Poland, the following conclusions can be drawn.

1. The expenses for counteracting the natural disasters' effects were co-financed from the ecological funds. One of them is the Fund for Environmental Protection and Water Management.

2. The expenses for permanent assets serving the water management in Lower Silesian voivodeship in the years 1998-2013 amounted approx. 1.5 billon US dollars indexed to the year 2013. The expenditures for levees in the years after the floods in 1997 and 2010 were significant higher. In the years 2001-2010, the number of kilometers of levees which were built amounted approx. $6 \mathrm{~km}$ every year. In the period 2011-2013, there were built approx. $8 \mathrm{~km}$ levees every year.

3 . The investing expenses for the low water retention in the area of examined region in the years 2003-2013 exceeded 19 million US dollars. The range of objects in Lower Silesian voivodeship in the years 2003-2013 amounted 525. The total increasing capacity in the examined period exceeded 5.5 million $\mathrm{m}^{3}$.

4. The share of the expenses for removing effects of natural disasters in expenditures for the public safety, fire and health protection is minimal.

\section{References}

[1] P. L. Abbott, Natural disasters, San Diego State University, San Diego 2009.

[2] D. Alexander, Natural disasters, Springer Science \& Business, Berlin 1993.

[3] GUS, Bank Danych Lokalnych, http://www.stat.gov.pl/bdl/app/strona.html?p_name=indeks, 27. 11. 2014.

[4] EM-DAT, http://www.emdat.be, 27.11.2014.

[5] M. Kachniarz, Efektywność usług publicznych - teoria i praktyka, Wydawnictwo Uniwersytetu Ekonomicznego we Wrocławiu, 2012.

[6] Kursy. Kursy kupna i sprzedaży walut obcych - tabela C, http://www.nbp.pl/kursy/kursyc.html, 28.11.2014.

[7] M. Maciejewski, M. S. Ostojski, T. Tokarczuk (red.), Dorzecze Odry: monografia powodzi 2010, IMGW - PIW, 2011.

[8] P. Migoń (red.) Wyjątkowe zdarzenia przyrodnicze na Dolnym Śląsku i ich skutki, Instytut Geografii i Rozwoju Regionalnego Uniwersytetu Wrocławskiego, Wrocław 2010.

[9] Z. Piepiora, Ekonomiczne aspekty lokalnej polityki przeciwdziałania skutkom katastrof naturalnych, Wyd. Zbigniew Piepiora, Kowary 2012.

[10] Z. Piepiora, Finansowanie przeciwdziałania skutkom powodzi w województwie dolnośląskim, in: E. Bogacka-Kisiel (Ed.), Nauki o finansach. Financial sciences, Prace Naukowe Uniwersytetu Ekonomicznego we Wrocławiu nr 2(11)/2012, UE we Wrocławiu, Wrocław 2012.

[11] Z. Piepiora, Przeciwdziałanie skutkom katastrof naturalnych w województwie dolnośląskim, in: S. Korenik, Z. Przybyła (Eds.), Gospodarka Przestrzenna XII, Wyd. Stowarzyszenie na Rzecz Promocji Dolnego Śląska, Wrocław 2009, ISBN 978-83-928165-0-8, Tom II. 
[12] Z. Piepiora, Natural disasters policy - the case study of the Lower Silesian Province, in: F. Adamczuk (Ed.), III Międzynarodowa Konferencja Młodych Naukowców Szkół Wyższych Euroregionu Nysa - Jelenia Góra 14-15 maja 2009, UE we Wrocławiu, Jelenia Góra 2009.

[13] J. Potocki, Funkcje turystyki w kształtowaniu transgranicznego regionu górskiego Sudetów, Wyd. Wrocławskie Towarzystwo Naukowe, Wrocław 2009.

[14] H. Słota (Ed.), Dorzecze Odry. Monografia Powodzi lipiec 1997, IMGW, Warszawa 1999.

[15] Terminology on Disaster Risk Reduction, United Nations / International Strategy for Disaster Reduction, Geneva 2009.

[16] Plan zagospodarowania przestrzennego województwa dolnośląskiego, Wojewódzkie Biuro Urbanistyczne, Wersja uchwalona przez Sejmik Województwa Dolnośląskiego uchwałą nr XLVIII/873/2002 z dnia 30 sierpnia 2002 roku. 